\title{
Bad aim: Separating the intentions and effects of American newsprint recycling legislation on landfill space, forest conservation and Canadian newsprint producers
}

\author{
Joshua Nasielski
}

This manuscript was prepared under the supervision of Professor Glenn Fox,
Department of Food, Agricultural \& Resource Economics, Ontario Agricultural College

\begin{abstract}
This paper argues that the American newsprint recycling laws passed during the late 1980s and early 1990s not only failed to achieve their stated environmental objectives, but failed so spectacularly that they actually contributed to further environmental harm. These laws, which imposed a recycled content standard on new newsprint production, had three intentions: to decrease landfill space requirements, to preserve forests, and to encourage the recycling of used newsprint. Insofar as the first two intentions are concerned, this paper finds that the American newsprint recycling laws had a negligible effect on both landfill space and forest conservation. But by succeeding in elevating the amount of newsprint recycling far beyond what it would otherwise be, industry compliance with these laws may have actually increased environmental harm. From a Canadian perspective, these laws essentially encouraged Canadian newsprint producers to import American newsprint waste. In addition, by imposing compliance costs on American and Canadian newsprint producers in the range of several billions of dollars, these laws prevented capital from being productively spent on other environmental initiatives. Surveying alternatives to government mandated recycling legislation, this paper ends by concluding that if governments wish to improve environmental outcomes through newsprint recycling, their best option may be to extend the functioning of markets.
\end{abstract}

$\mathrm{T}_{\mathrm{i}}$ his paper focuses on the difference between the intentions and effects of government mandated environmental policy. Specifically, this paper explores the American newsprint recycling laws that were passed during the late 1980s and early 1990s. Arising at state and federal levels of government, these laws imposed various recycled content standards on newsprint producers and importers, specifying recycled newsprint fibre ${ }^{\mathrm{a}}$ content in all newsprint production. ${ }^{\mathrm{b}}$

This paper begins by investigating the three intentions of these recycling policies: to decrease landfill space requirements, to preserve forests, and to increase the demand of old newsprint for recycling. This paper then compares the intentions of these laws to their actual effects in both the United States and Canada.

This report finds that the intentions of American newsprint recycling laws are largely incongruent with their effects. At best, recycling newsprint has no more than a minor beneficial impact on American and Canadian landfill space and forest conservation efforts. But the actual environmental outcomes of American newsprint recycling legislation are in fact far more insidious than simply being ineffective.
Because these laws succeeded in increasing the demand for old newsprint far beyond what otherwise would be, American newsprint laws contributed to further environmental damage. Basic economic theory suggests that newsprint recycling, like any activity, has an optimal level of production and consumption. By increasing recycling levels beyond such a point we encounter unintended environmental and economic costs.

This paper ends by exploring the free market environmentalist critique of government mandated recycled content standards. Such a perspective has been explored previously by Rutherford and Cairns. ${ }^{4,22}$ Free market environmentalism is a position which argues that the free market, supported by the consistent enforcement of property rights and common law, is the most effective means of preserving the environment for human welfare. Free market environmentalists note that determining the optimal level of recycling depends on acting upon decentralized and dispersed information; local time and place knowledge. The nature of such knowledge makes it impossible for governmental legislation to determine the optimal level newsprint recycling in an economy. In fact, only free markets can aggregate this information in a meaningful way. The 
final implication being that if governments wish to improve environmental outcomes through newsprint recycling their best option may be to improve the functioning of markets, not override them.

\section{The Environmental Intentions of Newsprint Recycling Laws}

Economist A.M. Freeman cites Earth Day, April $22^{\text {nd }} 1970{ }^{7}$ as the birth date of modern political environmentalism. According to Cordato, adherents consider resource use as inherently problematic. Simply put, resource use should be mitigated because of the environmental damage resource consumption causes, even if there is no link between these environmental damages and human welfare.

Kinnaman observed that the push to reduce, reuse and recycle household waste was an early part of the environmental movement. ${ }^{9}$ The logic is straightforward: the more goods we recycle and reuse, the lower the need for additional resource extraction. By recycling newsprint trees which would otherwise be cut down for processing would be left standing. The preservation of forest ecosystems, especially old growth forests, was an important goal of newsprint recycling legislation. ${ }^{12}$

Apart from the perceived beneficial impact of recycling due to reduced resource consumption, Wiseman notes the utilization of landfills also poses a problem for the environmental movement. ${ }^{28}$ According to Wiseman, ${ }^{28}$ the generic case against landfilling can be summarized as follows: society is generating waste at an increasing rate while our landfilling capacity is continuing to decrease; we will inevitably run out of space to put our waste. Again, the outcome is clear, the more waste we recycle the less landfill space we will need. According to Franklin Associates, paper and paperboard historically comprised the largest single component of landfills in the United States by weight. Because of this, newsprint was an early target for recycling initiatives.

Taken together these two environmental concerns formed the main rationale for the development of early recycling laws.

\section{A History of Newsprint Recycling Laws in Canada and the United States}

Historically newsprint recycling laws can be divided into two categories. The first and earliest laws, characterized by the Resource Conservation and Recovery Act (1976) in America and Ontario's Waste Reduction Action Plan (1991) focused on diverting recyclable materials from the municipal solid waste stream. ${ }^{c}$ These laws focused on increasing the supply of recyclable materials by requiring municipal governments to implement household recycling programs. ${ }^{23}$ Materials collected from households could then be sold to private businesses for further processing. Smith notes that municipalities initially hoped that the revenues generated from selling recyclable materials would compensate for the large costs associated with collecting, sorting and storing them. ${ }^{23}$

With respect to newsprint in the United States and Canada, these municipal recycling programs succeeded so well in collecting old newsprint that its price essentially collapsed. ${ }^{15,23}$ Smith notes that there had always been a small but financially viable private newsprint recycling industry in both the United States and Canada, ${ }^{23}$ and markets for these materials were already developed prior to the implementation of these recycling laws. For reasons that will be explained later in the paper, newsprint producers could not handle the sudden increase in supply of old newsprint. According to Smith, by 1989 the price of old newsprint in some U.S. regions was $\$ 0 .{ }^{23}$ In many cases, municipalities paid paper processors to haul newsprint away. ${ }^{12}$ As municipalities began to realize they could not rely on the revenue generated from selling recyclables to cover their costs, recycling programs began to rely on tax revenues to maintain their operations. ${ }^{15}$, ${ }^{23}$ A second category of newsprint recycling laws, coming into force at a later date relative to the first category, focused explicitly on increasing the demand for old newsprint (H.R. 873). This category of newsprint recycling law appeared only in the United States.

On February $6^{\text {th }} 1991$, the Newsprint Recycling Incentives Act (H.R. 873) was passed by the United States House of Representatives. The Act placed new recycling requirements, including a recycled content standard, on both domestic and foreign producers of newsprint used in the United States. The Newsprint Recycling Incentives Act (H.R. 873) mandated a minimum recycled fibre content of $20 \%$ for all new newsprint produced or imported into the United States by the end of 1992, a percentage which would increase by $2 \%$ each subsequent year for the next ten years. ${ }^{\mathrm{d}}$ The Newsprint Recycling Incentives Act (H.R. 873) notes that "The demand for old newspaper waste needs to be increased and to provide both an outlet for the rapidly increasing glut of old newspaper waste."

The Newsprint Recycling Incentives Act (H.R. 873) was similar to several State statutes being developed and implemented during the same time. Between 1990 and 1991, 13 other U.S. states enacted statutes mandating minimum recycled fibre contents in newsprint sold in the state. ${ }^{3}$

Although Canadian governments did not implement similar demand-side newsprint recycling legislation, the Canadian newsprint industry was directly affected by the American recycling laws. ${ }^{\mathrm{e}}$ According to Laplante and Luckert, 53\% of the newsprint consumed in the United States in 1990 was manufactured in Canada. ${ }^{13}$ The United States was also the most important newsprint market for Canadian producers: $80 \%$ of their production was sold to American businesses. ${ }^{12}$ It becomes reasonable to assume that in order to correctly asses the outcomes of American newsprint 
recycling laws, the environmental and economic effects in both the United States and Canada must be investigated.

\section{Measuring the Impacts: The Landfill Capacity Problem}

The effect of newsprint recycling laws on North American landfill space was estimated in a paper by Laplante and Luckert. ${ }^{12}$ Cumulatively, they estimate that newsprint recycling would save $3.4 \%$ of the total North American landfill space required between 1988 and 2010.

Laplante and Luckert's 1993 prediction overestimates landfill space savings. They ignore the landfill destined waste produced during the newsprint recycling process itself. Before large quantities of old newsprint can be incorporated into new newsprint manufacture, the ink printed on old newsprint must be removed. ${ }^{14}$ This process, known colloquially as de-inking, separates the valuable fibres from the valueless ink and other contaminants. ${ }^{14}$ The amount of ink removed is substantial and forms a viscous sludge which is dried further and then landfilled. Laplante and Luckert note that on a volume basis, recycling newsprint produces more landfill waste than producing an equivalent amount of new newsprint. ${ }^{13, \mathrm{f}, \mathrm{g}}$ Producing one ton of recycled newsprint creates an additional 0.216 tons of landfill waste compared to producing one ton of virgin newsprint. ${ }^{13}$

Taking this into account in their next paper, Laplante and Luckert find the effect of newsprint recycling on landfill space is likely to be much lower than originally thought, especially in Canada. ${ }^{13}$ Laplante and Luckert predicted that Canadian newsprint producers would need to import old newsprint from the United States in order to recycle enough fibres to meet the recycled content requirements of American newsprint recycling laws. ${ }^{13}$ Because the landfilled waste generated by recycling newsprint is greater than the landfilled waste generated by producing new newsprint, Canada would essentially be importing American landfill waste. Luckert and Laplante predicted that if the entire United States complied with the federal newsprint recycling laws starting in 1990, Canadian landfill requirements would actually increase. ${ }^{13, \mathrm{~h}}$

As Laplante and Luckert predicted, Canadian imports of old newsprint from the United States, as measured in metric tons, have increased substantially since the minimum recycled content laws were passed in the United States. ${ }^{13}$ This trend is illustrated in Table 1, which also shows the virtual landfill waste imported from the United States due to sludge produced during the de-inking process.

\section{Measuring the Impacts: North American Forest Conservation}

Laplante and Luckert also predicted the impacts of American newsprint recycling laws on American and Canadian forests. ${ }^{12}$ Cumulatively, through 1990 to 2010 , they predicted
Table 1: Old Newsprint Imported into Canada from the United States and Related Virtual Waste Imports from 1990 to 2006

\begin{tabular}{|c|c|c|}
\hline Year & $\begin{array}{l}\text { Old Newsprint } \\
\text { Imported from United } \\
\text { States }\end{array}$ & $\begin{array}{l}\text { Virtual Waste Imported } \\
\text { from the United States }{ }^{1}\end{array}$ \\
\hline & Metric Tons & Cubic Meters $\left(\mathrm{m}^{3}\right)$ \\
\hline 1990 & 257 & 28.2 \\
\hline 1991 & 259 & 28.42 \\
\hline 1992 & 231 & 25.35 \\
\hline 1993 & 231 & 25.35 \\
\hline 1994 & 313 & 34.34 \\
\hline 1995 & 465 & 51.02 \\
\hline 1996 & 568 & 62.33 \\
\hline 1997 & 688 & 75.49 \\
\hline 1998 & 577 & 63.31 \\
\hline 1999 & 503 & 55.19 \\
\hline 2000 & 564 & 61.89 \\
\hline 2001 & 357 & 39.17 \\
\hline 2002 & 553 & 60.68 \\
\hline 2003 & 689 & 75.6 \\
\hline 2004 & 1008 & 110.61 \\
\hline 2005 & 1128 & 123.77 \\
\hline 2006 & 994 & 109.07 \\
\hline
\end{tabular}

Source: Created from data collected from the Paper Recycling Association

that newsprint recycling legislation would preserve 46,754 cubic meters of standing timber. This represents the conservation of $0.43 \%$ of the total standing timber volume on forested land in the United States and Canada.

It is likely that Laplante and Luckert overestimated the amount of timber saved by the American newsprint recycling laws. ${ }^{12}$ First, about one third of the pulpwood used in newsprint production comes from sawmill and paper product waste. ${ }^{28}$ If newsprint producers simply substitute old newsprint for sawmill wastes instead of virgin fibre ${ }^{i}$ then newsprint recycling legislation will not decrease the demand for virgin fibre. But even if old newsprint displaces some of the demand for virgin fibre, it will not preserve the natural forests that people imagine they are saving when they recycle newsprint. Much of the virgin fibre used in newsprint production comes from man-made tree plantations, not natural forests. ${ }^{28}$ Thus, although newsprint recycling legislation may save trees it will not protect natural forests from being turned into newsprint. ${ }^{28}$ 


\section{MASTEPAPER UTILIZATION, \$}

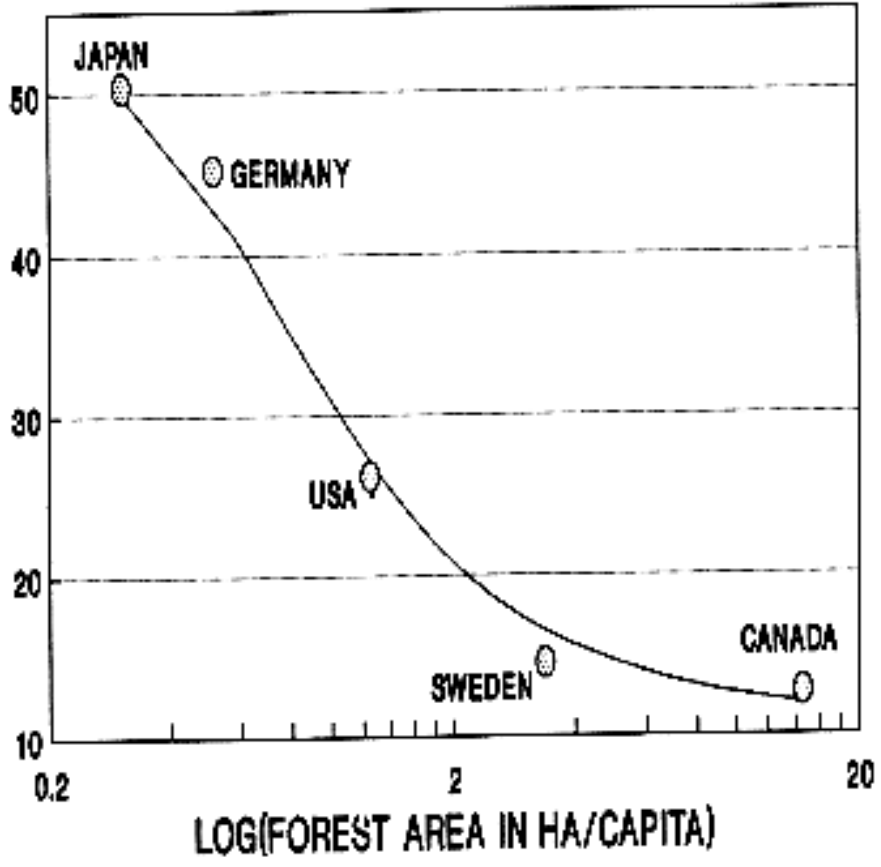

Figure 1: Wastepaper Utilization and Forest Area Per Capita: Data from 5 countries, 1993

Source: Taken from a report prepared for Forestry Canada by Temanex Consulting Inc. (1993)

\section{Measuring the Impacts: The Demand for Old Newsprint}

American newsprint recycling laws did succeed in increasing the amount of recycled fibre used in new newsprint production. The content of recycled newsprint fibre in new newsprint production increased from $11.4 \%$ to $16.0 \%$ between 1987 and 1992. ${ }^{12}$ By 2008, the average recycled content in North American newsprint had increased to $30 \% .{ }^{24}$ Note that the recycled content standards mandated under the Newsprint Recycling Incentives Act were not reached on time. This may be because compliance is difficult to enforce. Howard notes it is difficult to measure the recycled content of newsprint once it is printed. ${ }^{11}$

\section{Measuring the Impacts: Conclusion}

So far this paper has reviewed the three intended effects of the American newsprint recycling laws: decreasing the need for landfill space, preserving natural forests and increasing the demand for old newsprint. At best, newsprint recycling has had a small beneficial impact on landfill space and forest conservation. At worst, it has had a slightly negative environmental impact.
But, American newsprint recycling laws did increase the amount of recycled fibre used in new newsprint production in both Canada and the United States and in this sense they were successful. However this increase in newsprint recycling came with non-trivial costs to newsprint producers. The next section will examine the economic impacts of the American newsprint recycling laws on Canadian newsprint producers.

\section{The Economic Costs of American Newsprint Recycling Laws on Canadian Newsprint Producers}

Historically Canadian newsprint producers have incorporated very small amounts of old newsprint into new newsprint production. ${ }^{6,26, j}$ Although small amounts of old newsprint can be added to the newsprint production process without specialized equipment, recycling large volumes of newsprint require capital investments such as de-inking facilities. ${ }^{6}$

According to Tenemax, such capital investments have never been economically feasible for Canadian newsprint producers. ${ }^{26}$ Van Beukering and Bouman, in analyzing the domestic paper recycling industries of 56 countries, identified two reasons why Canadian newsprint producers would not have found large scale newsprint recycling economically sound. ${ }^{27}$ Canada is endowed with a large timber stock and has access to relatively cheap energy. ${ }^{27}$ This makes newsprint production from virgin fibre relatively inexpensive. In addition, Canada's low population density, located far from newsprint production facilities, would make collecting and transporting old newsprint relatively expensive. $^{26,} 27$ Figure $\mathbf{1}$ and Figure $\mathbf{2}$ reinforce Van Beukering and Bouman conclusions by illustrating the trends which have traditionally discouraged paper recycling in Canada. Figure 1 illustrates the relationship between forest area per capita and wastepaper recycling rates in various countries. ${ }^{\mathrm{k}}$ Figure 2 shows the relationship between wastepaper recycling rates and population density in various countries. Canada has both the lowest population density, the most forest area per capita and the lowest wastepaper recycling rates of all the surveyed countries.

In summary it should be no surprise that Canada has had historically low levels of newsprint recycling, given the country's access to large timber resources and low population density.

The Canadian newsprint industry reacted quickly to the sudden change of incentives governing newsprint recycling, from economic and market forces which kept newsprint recycling at low levels prior to the early 1990's, to American newsprint recycling laws which forced newsprint producers to meet recycled fibre targets. Bourdages reports that between 1990 and 1993, the Canadian newsprint industry spent $\$ 4.77^{1}$ billion on new recycling equipment and infrastructure. ${ }^{3}$ In 1990, there was only one paper mill in 


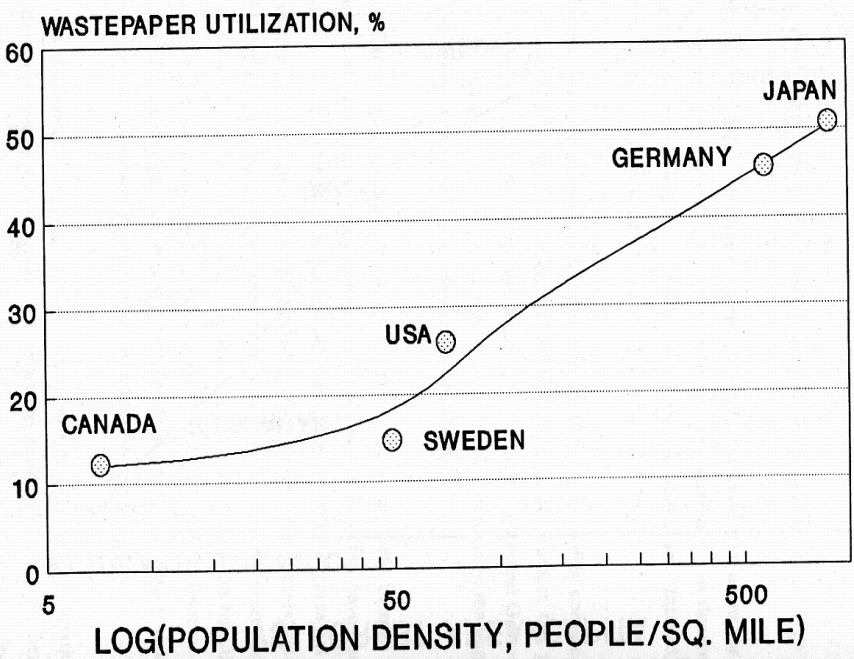

Figure 2: Wastepaper Utilization Population Density: Data from 5 countries, 1993

Source: Taken from a report prepared for Forestry Canada by Temanex Consulting Inc. (1993)

Canada which incorporated substantial amounts of recycled fibres into its newsprint production processes. By 1993, there were 20 paper mills producing newsprint made partly from recycled fibres. ${ }^{3}$ De-inking facilities, which allow for large volumes of old newsprint to be turned into viable fibres for new newsprint manufacture, increased from a single Canadian plant in 1988 to 16 in $1993 .{ }^{3}$ By 2006 there were 41 paper mills in Canada using recycled newsprint in their

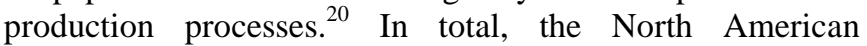
newsprint industry invested an estimated $\$ 8$ billion in order to meet the targets set by the newsprint recycling legislation. Even with these additional investments, in many cases recycling old newsprint into new is still more expensive than simply using virgin fibre. ${ }^{29}$

In summary, the economics of newsprint recycling in Canada make little sense. Canadian newsprint producers have the advantage of abundant natural resources which makes virgin newsprint inexpensive to produce while having the disadvantage of being located far away from sources of old newsprint. The large costs imposed on Canadian newsprint producers by American newsprint recycling legislation cannot be justified by their environmental benefits, simply because these environmental benefits do not exist.

\section{The Free Market Environmentalist Perspective: Introduction}

Free market environmentalism is a position which argues that the free market, supported by the consistent enforcement of property rights and common law is the most effective means of preserving the environment for human welfare. The perspective offers a strong critique of governmental regulations such as the newsprint recycling laws this paper has focused on.

Free market environmentalism, like much of the standard microeconomic principles it is based on, measures value in terms of willingness to pay or willingness to be paid. Conventional environmentalists see the environment as something that is literally priceless and intrinsically valuable. Political intervention on behalf of the environment is seen as something that ought to be done. But from the perspective of a free market environmentalist, the desire to conserve the environment is simply one sophisticated taste among many. The desire to preserve endangered species such as the Northern Spotted Owl is no different than the desire to eat a hamburger. Willingness to pay is the only relevant metric in determining the value of a particular thing or action. Rather than something that must be circumvented, the free market is an institution that best aligns self-interest with the common good. By satisfying individual preferences, measured objectively in terms of willingness to pay, society will collectively get the level of environmental quality it desires. It follows that political intervention on behalf of the environment is no less warranted than intervening in how individuals dress their hamburgers. Regardless, perhaps paradoxically, free market environmentalists also argue that many of their policy recommendations offer greater environmental benefits than current government legislation.

\section{The Free Market Environmentalist Perspective: Why} Newsprint Recycling Laws Have Failed

When viewed through the lens of microeconomics it is immediately apparent why the American newsprint recycling laws failed. Firstly, such recycling legislation ignores the fact that newsprint recycling, like any activity, has an optimal level of production and consumption. Recycling is not always the best option, whether defined by environmental or economic outcomes. By artificially increasing recycling levels beyond the optimal level of production through governmental recycling legislation, we encounter unintended environmental and economic costs. These costs may not be explicit but appear rather as opportunity costs. Consider that the Canadian newsprint industry invested $\$ 4.77$ billion in recycling machinery and equipment between 1990 and 1993. Money that could have been spent on purchasing forests for conservation or other environmental projects was instead wasted due to investments necessitated by American recycling laws. Economists consider the benefits forgone by these investment decisions (e.g. the forests that could have been protected) as costs.

This concept is explained graphically in Figure 3. It illustrates the fact that marginal benefits of newsprint 


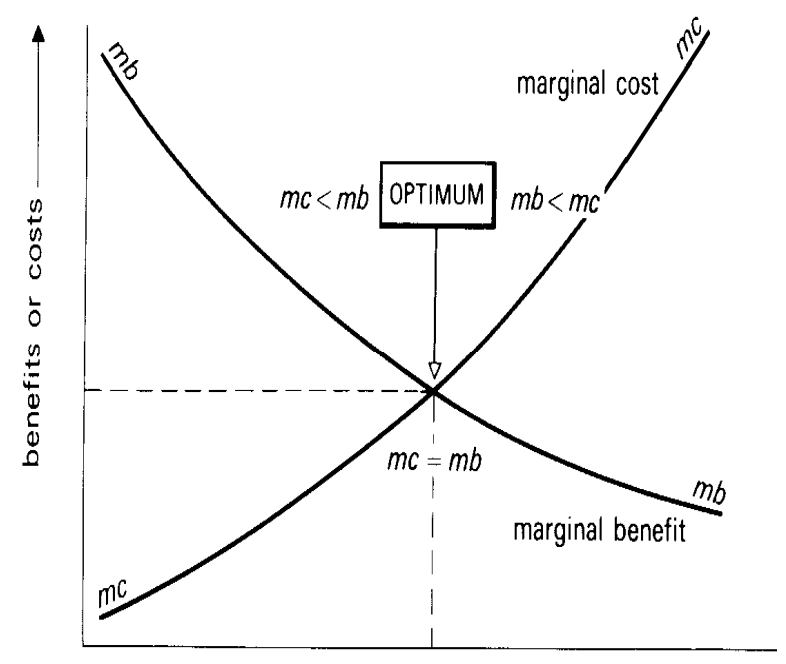

Figure 3: A Conceptual Graph of the Marginal Costs and Marginal Benefits of Newsprint Recycling

Source: Park (1999)

recycling decrease while the marginal costs, which include opportunity costs, increase. At some point recycling causes environmental damages. In spite of large increases in newsprint recycling levels, coming at great cost to Canadian newsprint producers, there is little to show in terms of environmental benefits (i.e. forest conservation and landfill space usage).

This paper takes the free market environmentalist perspective and proposes that the optimal level of newsprint recycling emerges on its own without government intervention, thus implying that the historically low levels of newsprint recycling in Canada were in fact optimal. If historical recycling levels were to the left of the equilibrium, then any increase in newsprint recycling levels would have yielded positive environmental benefits. As the preceding sections have shown, this is not the case.

\section{The Free Market Environmentalist Perspective: How Markets Arrive at the Optimum}

Nevertheless, if good recycling policy requires only an accurate estimation of the optimal level of recycling in an economy then a solution to the problem is straightforward. If the American newsprint recycling laws failed because they overestimated the optimal level of newsprint recycling, government can simply lower the recycled content standard closer to the optimal level and the problem is solved. Governmental legislation is still a viable option, it only needs revision.
Free market environmentalists counter this conclusion with an argument most famously put to paper by F.A Hayek in his 1945 article "The Use of Knowledge in Society". In it, Hayek defines two types of knowledge: scientific and economic. Scientific knowledge such as the theory of gravity is true at all times in all places. This type of knowledge can be aggregated in textbooks and taught in schools. Economic knowledge, on the other hand, is highly time and place specific and only a few people have access to such knowledge before it becomes obsolete. Markets give people the ability to act on the local information they have, making the best possible use of resources at any given moment. Governmental regulations cannot easily adapt to such changes in information. One day it may make little sense, either environmentally or economically, to recycle newsprint while the next day it may. Imagine a shipping barge carrying old newsprint washes ashore near a remote newsprint factory. It suddenly makes sense for that factory to start recycling. A blanket regulation mandating recycled content standards ignores the fact that no one individual or government has enough information, or the right kind of information, to determine the optimal level of newsprint recycling.

Hayek's paper had another point. Individuals do not have direct access to the time and place information of other locales. ${ }^{10}$ The economic knowledge of the larger world is mostly hidden from individuals. Hayek contends that only the price system emerging out of free markets can communicate the economic information of the larger world. By fluctuations in the market price of newsprint, for instance, the essential economic information can be abstracted from the particulars of time and place and transmitted to newsprint producers everywhere.

When free market environmentalists use the term optimal, they do not use it in the Platonic sense. The optimal level of newsprint recycling does not exist as an ideal form, waiting to be discovered by producers and consumers that can then adjust production and consumption accordingly. Rather the optimal level of newsprint recycling emerges as people act in response to events and information. The current level of newsprint recycling occurring at any given moment in an economy is by definition the optimal level of recycling. As long as markets are functioning properly, that is, as long as time and place knowledge can be acted upon and then accurately transmitted to others through the price system, the optimal level of newsprint recycling will be produced.

\section{The Free Market Environmentalist Perspective: Alternative Institutions}

As stated before, free market environmentalism cannot offer specific solutions to environmental problems. Instead of relying on outside experts, free market environmentalists recommend, in the words of Don Boudreaux: 
"allowing the minds of millions of creative people, each with different perspectives and different bits of knowledge and insights, to each voluntarily contribute his own ideas and efforts toward dealing with the problem. It is to recommend not a single solution but instead a decentralized process that calls forth many competing experiments and, then, discovers the solutions that work best under the circumstances."

The institution that allows this process to occur is the free market. Insofar as policy prescriptions for environmental problems, free market environmentalists can only recommend the further extension of free markets and the laws that support their operation. Traditional free market environmentalist policy prescriptions simply extend the power of market institutions to where they have previously been denied.

Hayek's insight suggests that in order to achieve an optimal level of newsprint recycling we should price waste disposal correctly. Many municipalities charge a flat fee for waste disposal services. ${ }^{28}$ The message being transmitted by such a pricing system is that the cost of producing additional waste is zero. From the perspective of municipal waste management services, which pay a per-ton landfilling fee, this is clearly untrue. ${ }^{28}$ By providing a marginal unit cost and creating a per-bag garbage fee, households have a direct incentive to reduce waste. ${ }^{\mathrm{m}}$ Although current municipal waste systems make it difficult to determine a market price for waste disposal a per-bag unit fee represents an improvement over current practices.

Empirically, many studies have been done on per-unit garbage fees and their effect on household waste generation. Disagreements remain over the method of determining the optimal per-unit garbage fee, which reflects the marginal cost of disposing the additional garbage, and actual fees are usually held below these prices for political reasons. ${ }^{8}$ However, most studies conclude that per-unit garbage fees do succeed in reducing the weight of garbage that households drop off at the curb. ${ }^{8,17, \mathrm{n}}$ This suggests that increasing the price of waste disposal at the margin can be used effectively to reduce waste generation.

Anderson and Leal make the case that private property rights, strongly defended, have the possibility of more adequately ensuring that forests are protected than newsprint recycling laws. ${ }^{1}$ Although newsprint recycling laws may preserve forests in the larger sense of the term, they do not necessarily protect the forests that people value most highly. When people place a value on a standing forest, whether for recreational, aesthetic or ecological reasons, a marketplace will allow these values to be expressed through buying and selling forest lands. With a well functioning market, forests are harvested when the value of the timber harvest outweighs the value of using the forest in any other way. ${ }^{1}$ Such a market arrangement helps uncover the time and place specific information that governmental regulations cannot. The particular forests people want to save, for whatever reason, will be saved, while the forests that are best used as timber will be used as timber.

Anderson and Leal offer many examples illustrating the power of private property rights to protect environmental amenities. ' Private conservation organizations now own $2,023,428 \mathrm{Km}^{2}$ of land in the United States, protecting these areas from environmental degradation. ${ }^{1}$ The Nature Conservancy, Conservation International, the Audubon Society and many other private organizations succeed in preserving and protecting land without government encouragement or oversight. ${ }^{1}$ In Canada, where $93 \%$ of forest land is owned by the government, the situation is more complex. ${ }^{6}$ Forests are typically leased instead of purchased. ${ }^{21}$ However the general principle still stands: long-term leases to non-timber interests could preserve the forests that people truly want to preserve.

\section{Conclusions}

In the preceding sections this paper has studied and separated the intentions and effects of American newsprint recycling laws on North American forest conservation, North American landfill space, and Canadian newsprint producers. It has concluded that although the laws did succeed in increasing the recycled fibre content in new newsprint production, at great cost, little has been achieved in terms of either landfill space or forest conservation. This paper concludes that American newsprint recycling laws have pushed newsprint recycling to the right beyond the optimum (or equilibrium point) as illustrated in Figure 3 . Furthermore, using empirical data and Hayek's theoretical insights, this paper argues from that the historically low levels of newsprint recycling in Canada were in fact optimal. $^{10}$ It concludes by providing two free market environmentalist policy recommendations to increase forest conservation and reduce landfill space usage.

Regardless of free market environmentalism's policy prescriptions, which suggest improved environmental quality over governmental legislation, there remains a rift between free market environmentalists and conventional political environmentalists. Ostensibly, both political and free market environmentalists value the environment, but there remains a divide that is largely aesthetic. Political environmentalists sense that a preference for a healthy environment is not like other conventional wants. They desire a society and government that will recognize this explicitly uphold the intrinsic value of the environment. On the other hand, free market environmentalists argue that such a task, even if desired, is impossible given the nature of the information needed to do the job right. This conflict has yet to be fully resolved. 


\section{ENDNOTES}

${ }^{a}$ Fibre refers to the main input of the newsprint production process: cellulose pulp derived from wood products or recycled from old newsprint ${ }^{12}$

$\mathrm{b}$ These laws, whose specifics will be covered later in this paper, will collectively be referred to as the American newsprint recycling laws for the rest of this paper. ${ }^{c}$ A short note on the regulatory jurisdiction of Canadian recycling laws is warranted. According to Dosman et al. federal, provincial and municipal governments all have legislative authorities with respect to waste management. At the federal level there is little direct waste management legislation except in the way of delegating legislative responsibilities for waste management to provincial governments. Provincial governments have largely focused on the creation of waste management objectives and action plans while giving municipal governments the responsibility of implementing them.

${ }^{\mathrm{d}}$ It would seem that enforcement of such a law would be difficult, especially since most newsprint is produced in another country (Canada). The law mandated the Environmental Protection Agency to enforce the Act, providing them initially with $\$ 1.2$ million dollars. In either case, both American and Canadian newsprint producers have taken the law seriously. It is estimated that Canadian and American newsprint producers spent more than $\$ 8$ billion between 1991 and 1996 on improving and increasing their newsprint recycling capabilities (Business Week, 1991) ${ }^{\mathrm{e}}$ Under Canadian recycling laws, newsprint recycling is voluntary. Therefore, the effect of Canadian recycling laws on Canadian newsprint producers is assumed to be zero.

${ }^{\mathrm{f}}$ Note that virgin newsprint production generates various wastes and pollution that cannot be landfilled. ${ }^{5}$

${ }^{g}$ Also note that options for recycling sludge produced by the de-inking process is limited at this time. ${ }^{18}$

${ }^{\mathrm{h}}$ Note again that other potentially important environmental metrics would be positively impacted ${ }^{26}$

${ }^{\mathrm{i}}$ Virgin fibre refers to the new and unblemished condition of the fibres used to make new newsprint.

${ }^{\mathrm{j}}$ In 1987, the average recycled content of new newsprint produced in Canada was $2 \%$.

${ }^{\mathrm{k}}$ Note that Figure 3 does not take into account access to cheap energy resources. Given that Van Beukering and Bouman found Canada does have access to cheap energy resources, this should not affect the conclusions drawn from Figure 3 . $^{27}$

${ }^{1}$ In 2008 dollars

${ }^{\mathrm{m}}$ A truly free market environmentalist solution would not only charge waste producers the full costs of waste disposal, but would also privatize waste management services. Private businesses would offer waste disposal services to households for-profit. The price of waste disposal generated in such a free market would be more accurate that the per-bag free municipalities set. Also, these businesses, once waste has been collected, would then have an incentive to recycle whatever it is financially viable to do so.

${ }^{n}$ Most of these studies also report an increase in recycling rates due to per-unit garbage fees. Because per-unit garbage fees increase newsprint recycling, a true comparison of newsprint recycling laws and per-unit garbage fees and their effects on landfill space is not possible.

\section{REFERENCES}

1. Anderson, T.L and Donald R. Leal (2001) Free Market Environmentalism, Palgrave, New York

2. Boudreaux, D. (2006) A Simple Rule for a Complex World Café Hayek. Retrieved 28 Mar. 2009 from http://cafehayek.typepad.com/hayek/2006/03/a_simple_ rule f.html

3. Bourdages, J.L.. Library of Parliment Research Branch. Science and Technology Division. Paper Recycling in Canada: A New Reality. Ottawa: Library of Parliment, 1993.

4. Cairns, Alexander (2007) "Regulating Ontario's fresh water resources: A free market environmentalist perspective" Studies by Undergraduate Researchers at Guelph 1(1): 29-39

5. Colodey, A.G. (1989) "Environmental Impact of Bleached Pulp and Paper Mill Effluents in Sweden, Finland, and Norway: Implications to the Canadian Environment" Environment Canada discussion paper

6. Environment Canada (2005) Forest Biological Diversity Biodiversity Convention Office. Retrieved 28 May 2009 from http://www.cbin.ec.gc.ca/enjeuxissues/forets-aaaaaaforest.cfm?lang=eng

7. Freeman, A.M (2002) "Environmental Policy Since Earth Day 1: What Have we Gained?" Journal of Economic Pespectives 16:125-146

8. Fullerton, D. and T.C. Kinnaman (1996) "Household Response to Pricing Garbage by the Bag" American Economic Review 86(4): 971-984

9. Kinnaman, T.C. (2006) Policy Watch: Examining the Justification for Residential Recycling Journal of Economic Perspectives 20(4): 219-232

10. Hayek, F.A. (1945) The Use of Knowledge in Society The American Economic Review 35(5): 519-530

11. Howard, R.C (1991) "Effects of Recycling on Paper Quality" Paper Technology 32:20- 25

12. Laplante, B and Martin Luckert (1993) "The Wastepaper Dilemma: Can newsprint recycling legislation kill two birds with one stone?" Society and Natural Resources 6(3):361-379

13. Laplante, B and Martin Luckert (1994) "Impact of Newsprint Recycling Policies on Canadian Waste 
Production and Forests" Canadian Public Policy 20(4): 400-414

14. McDonald, M (1971) Paper Recycling and the Use of Chemicals, Noyes Data Corporation, New Jersey

15. McRobert, David. (1994). "Ontario's Blue Box System: A Case Study of Government's Role in the Technological Change Process, 1970-1991”. Osgoode Hall Law School, York University.

16. Micheal, J (1998) "Recycling, International Trade, and the Distribution of Pollution: The Effect of Increased U.S Paper Recycling on U.S. Import Demand for Canadian Paper" Journal of Agriculture and Applied Economics 30(1): 217-213

17. Miranda, M.L., Everett, J.W., Blume, D. and B.A. Roy (1994) "Market-Based Incentives and Residential Municipal Solid Waste" Journal of Policy Analysis and Management 13(4): 681-698

18. Ochoa de Alda, J.A.G (2008) Feasibility of Recycling Pulp and Paper Mill Sludge in the Paper and Board Industries Resources, Conservation and Recycling 52:965-972

19. Park, Chris (1999) "Natural Hazards" Faculty Webpage, University of Lancaster. Retrieved 27 Mar. 2009 from http://www.lancs.ac.uk/staff/gyaccp/hazards/

20. Paper Recycling Association "Pulp and Paper Products Council: Paper Recycling Industry Overview". Retrieved $25 \quad$ Feb. 2009 from http://www.pppc.org/en/1_0/index.html.

21. Pearse, Peter (1988) "Property Rights and the Development of Natural Resource Policies in Canada" Canadian Public Policy 14(3): 307-320
22. Rutherford, Jacquelyn (2008) "Too many boats chasing too few fish: The collapse of the Atlantic groundfish fishery and the avoidance of future collapses through free market environmentalism". Studies by Undergraduate Researchers at Guelph 2(1): 11-17

23. Smith, M. (1994) The U.S. Paper Industry and Sustainable Production MIT press, Cambridge, Massachusetts

24. Stokes, Leah (2008) "Environmental newsprint at the tipping point" The Publisher May 2008. Retrieved 27 Mar. 2009 from http://marketsinitiative.org/uploads/Publisher-0805.pdf

25. "Stewardship Ontario, History of Blue Box in Ontario." Stewardship Ontario - The Industry Funding Organization for Ontario's Blue Box Program and Municipal Hazardous or Special Waste Program. Stewardship Ontario. Retrieved 25 Feb. 2009 http://www.stewardshipontario.ca/corporate/bbhistory/b bontario.htm.

26. Temanex Consulting Inc. The Role of Wastepaper in the Canadian Pulp and Paper Industry. Rep. Vancouver: Tenemax Consulting Inc., 1993.

27. van Beukering, $P$ and Mathijs Bouman (2001) "Empirical Evidence on Recycling and Trade of Paper and Lead in Developed and Developing Countries" World Development 29(10):1717-1737

28. Wiseman, C (1992) "Government and Recycling: Are we Promoting Waste?" Cato Journal 12(2): 443-460

29. Yang, D., Symonds, W and Lisa Driscoll (1991) "Recycling is Rewriting the Rules of Papermaking" Business Week April 22 ${ }^{\text {nd }} 1991$ 